\title{
FINANCING CONSTRAINTS, INTERNAL CONTROL QUALITY AND COST STICKINESS
}

\author{
Yufeng $\mathrm{CHEN}^{1,2^{*}}$, Yanbai $\mathrm{MA}^{3}$ \\ ${ }^{1}$ School of Economics, Tailong Finance School, Center of Modern Business, Zhejiang Gongshang \\ University, 18, Xuezheng Street, Jianggan District, 310018 Hangzhou Zhejiang, China \\ ${ }^{2}$ College of Business Administration, Capital University of Economics and Business, \\ 121, Zhangjia Intersection, Fengtai District, 100070 Beijing, China \\ ${ }^{3}$ School of Economics and Management, Lanzhou University of Technology, \\ 287, Langongping Road, Qilihe District, 730050 Lanzhou Gansu, China
}

Received 08 May 2020; accepted 26 February 2021

\begin{abstract}
Managers think that retaining resources is more effective than rebuilding resources after exhausting them. However, financing constraints have brought great uncertainty to this resource decision-making implemented by managers. Data of manufacturing listed firms in China from 2009 to 2017 are used here to explore the impact of financing constraints on cost stickiness. This paper finds that internal financing constraints have a significant promoting effect on cost stickiness, while debt financing constraints and equity financing constraints have a significant restraining effect on cost stickiness. The internal control quality has a moderation effect on this relationship. In a firm with low quality of internal control, internal financing constraints can enhance cost stickiness, but the weakening effect of external financing on cost stickiness is not affected by internal control quality.
\end{abstract}

Keywords: financing constraints, financing sources, cost stickiness, adjustment cost, cost management, asymmetric cost behavior, internal control quality.

JEL Classification: D21, G32, M11.

\section{Introduction}

Cost management is the main content of firm daily management, and also an important consideration factor in resource planning. In the practice of maximizing profits through cost management, there is an asymmetric relationship between the change of business volume and the related cost change. Anderson et al. (2003) defines this phenomenon as "Cost Stickiness": costs increase more when activity rises than they decrease when activity falls by an equivalent amount. Compared with the traditional cognition of cost theory, the increase or decrease of business volume leads to the change of firm cost no longer limited to linear relationship

*Corresponding author. E-mail: chenyufeng@gmail.com

Copyright (c) 2021 The Author(s). Published by Vilnius Gediminas Technical University

This is an Open Access article distributed under the terms of the Creative Commons Attribution License (http://creativecommons. org/licenses/by/4.0/), which permits unrestricted use, distribution, and reproduction in any medium, provided the original author and source are credited. 
(Noreen, 1991). What factors determine the asymmetric change of firm cost? Anderson et al. (2003) explains this problem from the perspective of adjustment cost, cost stickiness is the economic consequence of managers deliberately adjusting the resources invested in business activities. In order to cope with the change of business volume, managers need to increase firm resources or sell off firm assets according to strategic choice, which will cause adjustment cost (Anderson et al., 2003; Banker et al., 2013). Hence, cost stickiness can examine the behavioral bias behind resource allocation decisions (Bradbury \& Scott, 2018), which is important for explaining the asymmetry of business volume and cost changes in production and management (Banker et al., 2011).

Although adjustment cost is helpful to understand the description of cost stickiness on firm behavior of cost management. However, firms need adequate fund support for cost adjusting. In the transition stage of China's economy, an imperfect capital market has higher financing costs, which leads to financing constraints for firms (Fazzari et al., 1988). Doms and Dunne (1998) point out that financing cost is an important component of firm's adjustment cost. Therefore, financing constraints will affect cost stickiness via adjusting costs. This is because, although it is more effective to retain resources than to rebuild resources after exhausting them, it will help firms quickly resume production and profit in the future (Baumgarten, 2012). However, retaining redundant resources will occupy firm liquidity resources and increasing its financial risks (Chen \& Hu, 2017), so access to capital is an important determinant of cost stickiness (Cheng et al., 2016). This shows that alleviate financing constraints is the key to adjustment costs, and it is also a way for management to improve business performance through cost control. As a monitoring and governance mechanism, internal control can effectively restrain the self-interest motivation of the management and alleviate the principal-agent conflict (Jensen \& Meckling, 1976), improve the firm's operating efficiency and reduce information asymmetry (Cheng et al., 2014). This can well limit the managers' deliberate adjustment of the input resources, realize the reasonable control of costs and expenses, and then have an impact on cost stickiness. Then, how will financing constraints affect cost stickiness? How will internal control affect this relationship?

Among the extant literature, the study on cost stickiness mainly focuses on the specific characteristics of firms (e.g., Sun \& Liu, 2004; Dierynck et al., 2012; Yasukata, 2011; Chen et al., 2021, etc.) and there are few studies on how business circumstance affects cost stickiness (Li \& Zheng, 2017). There are also some literature beginning to study the impact of financing problems on cost stickiness from the perspective of financing market circumstance (Cheng et al., 2016; Chen \& Hu, 2017; Homburg et al., 2018). However, these studies don't distinguish the specific sources of financing constraints, or are limited to the macro environment of the capital market and don't comprehensively analyze the impact of financing constraints from different sources on cost stickiness. In addition, there are few studies on the correlation between internal control and cost stickiness. In summary, from the perspective of cost adjustment, this paper mainly analyzes the effect of internal financing, debt financing and equity financing constraints on cost stickiness, and the moderation effect of internal control quality on the relationship between them. Furthermore, this paper considers the differences between property rights and firm size to more comprehensively study the impact of factors that affect cost stickiness on this mechanism. 
The main contributions of this paper are as follows: on one hand, this paper focuses on the difference of cost stickiness caused by different sources of financing constraints under the background of China and analyzes the relationship between the two from the perspective of adjustment cost, which adds evidence from transitional and emerging market countries to the study of cost stickiness drivers. On the other hand, this paper brings internal control into the research framework of cost stickiness, discusses the impact on cost stickiness based on the connection between financing constraints and internal control, and expands the research content of influencing factors of cost stickiness. In addition, the research also has some practical value. Managers can understand the impact of financing costs from different sources on cost management, deepen their understanding of asymmetric cost behavior, and correct the behavior deviations behind resource allocation decisions.

The rest of this paper is structured as follows: Section 1 is literature review and hypothesis development, Section 2 is sample selection, model construction and variable definition, Section 3 is empirical analysis of the effect of financing constraints on cost stickiness, and the last section is research conclusion.

\section{Literature review and hypothesis development}

\subsection{Literature review}

In the early research on cost stickiness, its existence is a hot spot in the academic circle. Based on some existing research results (e.g., Banker \& Johnston, 1993; Noreen \& Soderstrom, 1997), Anderson et al. (2003) first confirmed the existence of cost stickiness in American listed firms. In addition, they also found that changes in sales revenue, macroeconomic circumstance, capital intensity and labor intensity are important factors affecting cost stickiness. Subramaniam and Weidenmier (2016) come to an asymmetric result similar to Anderson et al. (2003), but this conclusion has an additional condition: the cost will show sticky behavior when the income changes more than $10 \%$. This shows that cost stickiness has a certain threshold effect. Banker et al. (2011) provides strong evidence for the existence of cost stickiness from the theoretical framework and empirical evidence. They point out that cost stickiness arises because forward-looking managers make deliberate resource commitment decisions in the presence of cost adjustment.

As the existence of cost stickiness has become a consensus, more researchers pay attention to the characteristics, influencing factors and economic consequences of cost stickiness. Therefore, the existing literature which study on cost stickiness can be divided into three categories: additional evidence of cost stickiness, economic consequences of cost stickiness, and determinants of cost stickiness (Malik, 2012). For example, Hartlieb et al. (2020b) investigates the impact of an informal social attribute on asymmetric cost behavior, the result shows that generalized trust significantly increases cost stickiness. Hartlieb et al. (2020a) also examines the impact of community social capital on cost stickiness, their results show that managers' discretion plays an important role in cost behavior.

In terms of the determinants of cost stickiness, there are mainly three representative viewpoints. (1) Adjustment cost viewpoint: Anderson et al. (2003) and Yasukata (2011) indicate that managers will retain resources during a short period of decline in sales in the long run. 
They found that use retained resources can reduce costs and increase profits when sales increased. In addition, managers with the hope of generating earning in the future will try to maintain their resources to prevent the deprivation of future possible earnings (Salehi et al., 2018). Therefore, cost stickiness is the result of managers deliberately adjusting economic resources invested in business activities. (2) Principal-agent viewpoint: Chen et al. (2012) shows that the motivation of managers to build personal empire will cause cost stickiness. Driven by self-interest motivation, managers often use an excessive expansion of firm size as a means to enhance their interests by grasping more resources to expand personal interests such as status, power, reputation, etc. (3) Optimistic expectations of managers. Later, Chen et al. (2021) finds that future sales prospects are related to current degree of cost stickiness. Overconfidence of CEO and CFO will overestimate future demand and result in increased cost stickiness, which is based on optimistic expectations of management.

The role of cost stickiness is to intuitively reflect firm's cost management behavior, which helps managers to consider their resources when adjusting costs. It mainly emphasizes the effect of managers' behavior from its determinants. Moreover, principal-agent problems and managers' overconfidence will affect resource commitment decisions and lead to adjustment costs. This is also the theoretical foundation for the adjustment cost viewpoint. However, besides the influence of internal factors such as managers and firm characteristics, the change of cost stickiness has a wide relationship with the external environment of the firm. This is because the solution of macro problems will ultimately be implemented at the micro-level, and managers will make resource allocation decisions in response to the needs of environmental change. The capital market is one of the external circumstances that firms must face for sustainable operation, and it is also a platform for firms to solve financing constraints. Capital is the most important resource to a firm and capital cost is an important component of cost management. The financing problem is related to whether a firm can get sufficient financial support to adjust the cost. The decision of firms to adjust resources will eventually bring different magnitudes of cost stickiness.

In summary, this paper studies the impact of financing constraints on cost stickiness from the perspective of adjustment cost. The main reasons are as follows: First, it is more effective to retain resources than to rebuild resources after exhausting them (Baumgarten, 2012). Moreover, the cost of resource downward adjustment is higher than that of resource upward adjustment (Pfann \& Palm, 1993). As a result, the rate of cost increase caused by business volume change is faster than that of cost decrease. Adjustment cost viewpoint accords with the explanation of cost stickiness drivers. Secondly, financing constraints are more related to financing costs because they will affect the resources adjustment. As a result, the firm's decision to adjust resources will bring different degrees of cost stickiness. Thirdly, sufficient capital is an important guarantee for the success of firm operation. Firms need to provide sufficient fund support through financing to adjustment costs. However, there are financing costs and investment restrictions in the imperfect financial market in real economic activities. Firms will be more or less troubled by financing constraints, which will affect the degree of cost stickiness. Therefore, the perspective of adjustment cost is appropriate to integrate financing constraints and cost stickiness into the unified analytical framework and establishes the theoretical starting point of this paper. 


\subsection{Hypothesis development}

Doms and Dunne (1998) point out that financing cost is an important component of adjustment cost. Firm financing cost will affect cost adjustment and ultimately affect cost stickiness. Current research shows that firms with limited access to capital have lower current capacity expansion related to sales growth and result in anti-cost stickiness or cost stickiness (Cheng et al., 2016). This shows that financing constraints may dampen cost stickiness, so the change of cost stickiness will also reflect the impact of firm financing on cost management. Campello et al. (2010) finds that although firms with financing constraints will make plans to cut technology spending, employment and capital expenditure, they will also exhaust more cash and use more credit lines because they are worried that banks will restrict access and sell more assets to fund their operations in the future. Accordingly, there is a significant negative relationship between the asymmetrical behavior of cost and capital structure in firms with a high-level of cost stickiness (Prieto, 2019). Ultimately, firm's resource adjustment plan will change with the magnitude of financing constraints. Of course, different financing constraints come from different financing costs, so financing can provide different capital support to adjustment costs and the impact on cost stickiness is different.

The development of Chinese financial market lags behind the economic development, which sets constraints for firms to obtain external financing. In fact, Chinese firms use internal capital markets to ease financing constraints (Tan \& Ma, 2016). However, the firm's funds are always limited and excessive use of internal funds will increase the liquidity risk. Therefore, it is difficult to support the development of a firm only relying on internal financing. The development and further improvement of capital market will attract firms to focus on the external capital market. Then, firms can choose debt financing or equity financing, but it is generally considered that the cost of equity financing is lower than debt financing. Because equity financing can make full use of equity financing qualification, additional equity financing will not lead to financial difficulties compared with debt financing requiring collateral (Hall \& Lerner, 2010). Therefore, firms have different attitudes towards various financing constraints. Although internal financing and equity financing are more preferred financing sources for listed firms, they will also choose debt financing in case of insufficient funds. Appropriate financial leverage can reduce the cost of capital and help to improve the rate of return on capital.

Generally, internal financing is the capital allocation of firm itself, and managers have more rights of allocation, so they are more convenient to deliberately reserve resources; while debt financing and equity financing belong to external capital, which may obtain refinancing qualifications only by paying agreed interest costs and repaying principal and meeting the high rate of return demanded by investors. Therefore, firms need to adopt more effective and prudent investment strategies for debt financing and equity financing, it must be improved the speed of cost adjustment to get higher returns. So, managers will be more active in adjusting their attitudes towards debt financing and equity financing after capital is put into production and operation, which will help restrain cost stickiness. Therefore, hypothesis 1 is proposed in this paper.

Hypothesis 1. Internal financing constraints will exacerbate cost stickiness, while debt financing constraints and equity financing constraints will dampen cost stickiness. 
As noted above, financing constraints will affect cost stickiness via adjustment costs. However, the role of external environment is closely related to internal governance. Before considering the financing circumstance behind the capital market, the existing internal control environment may be different. Whether there are defects in internal control have an important effect on production and operation of firms? Firms with internal control weakness (ICW) are unlikely to provide managers with timely and accurate decision information to carry out resource management, so they need to pay more costs to achieve performance. Tang (2020) studied the impact of cost stickiness on the possibility of future losses and audit cost, and found that the possibility of future losses and audit cost will increase with the increase of cost stickiness. Navarro et al. (2020) also found that ICW would increase audit fees. In addition, when firms with ICW, the lack of supervision mechanism provides convenience for managers to adjust resources intentionally, and the operation efficiency cannot be improved. Therefore, firms with ICW have higher cost stickiness than for non-ICW firms (Kim et al., 2019). This is because the influence of ICW on cost stickiness comes from the problem of internal information control. It can provide managers and investors with true and complete decision information when internal control is sound, such as what kind of capital source should be used to ease financing constraints and how to adjust resources to reduce adjustment cost. Zhu and Yang (2019) find that supply chain financing can alleviate financing constraints faced by GEM listed firms, and the impact is more obvious in firms with low quality of internal control. This result shows that firms with low quality of internal control face greater financing constraints, but the supervision function of external financing can effectively alleviate this dilemma. It is suggesting that firms relying on internal financing may suffer greater financing constraints due to internal control defects. Therefore, it will face higher cost stickiness due to insufficient funds for cost adjustment and inefficient resource allocation. Based on this analysis, hypothesis 2 is proposed:

Hypothesis 2. In a firm with low quality of internal control, internal financing constraints can enhance cost stickiness. However, there is no difference in internal control quality in the effect of external financing constraints on reducing cost stickiness.

\section{Date, models, and variables}

\subsection{Date sources and models}

The data in this paper mainly from the CSMAR Database, in which the date of property rights from the shareholder control information table of the CCER Database, and the internal control index from the DIB Internal Control and Risk Management Database. According to the "Guidelines for Listed Firms' Industry Classification (Revised 2012)" issued by the China Securities Regulatory Commission (2012), the research object is Chinese manufacturing listed firms in the A-share market from 2009 to 2017. This period considers the following two factors: First, the financial crisis in 2008 has a huge impact on the financial situation of listed firms, which is different from the financial data of subsequent years. Second, in 2018, the China Securities Regulatory Commission revised the regulatory requirements on financing behavior of listed firms and promulgated the "Regulatory Requirements for Guiding and Regulating the Financing Behavior of Listed Firms". This regulation will affect the fundraising of listed firms. In order to enhance the comparability of empirical results, 2018 and later 
years should be taken as a new inspection cycle, which needs to be further explored. For instance, Hassanein and Younis (2020) took the financial crisis as a natural experiment to compare the changes of stickiness behaviors of firm costs pre, during and post the period of the event. Drawing on the conventions of most studies, this paper excluded ST firms, firms with incomplete data and missing values, and obtained a total of 7529 observations including 1515 listed firms. In order to avoid the influence of outliers, continuous variables are winsorized at the top and bottom $1 \%$.

The following model was proposed by Anderson et al. (2003) to measure cost stickiness:

$$
\log \left(\frac{\operatorname{Cost}_{i, t}}{\operatorname{Cos}_{i, t-1}}\right)=\beta_{0}+\beta_{1} \log \left(\frac{\text { Revenue }_{i, t}}{\text { Revenue }_{i, t-1}}\right)+\beta_{2} \log \left(\frac{\text { Revenue }_{i, t}}{\text { Revenue }_{i, t-1}}\right) \times D_{i, t}+\varepsilon_{i, t} \text {, }
$$

where Cost is operating costs, Revenue is operating revenue. $D$ is the dummy variable, which indicates that when the current year's operating revenue is lower than the previous year's operating revenue, the value is 1 , otherwise the value is 0 . In Model (1), $i$ represents each sample firm, and $t$ represents time. According to the definition of cost stickiness, $1 \%$ increase in operating revenue will increase by operating costs of $\beta_{1} \%$; if operating revenue falls by $1 \%$, the decrease in operating costs will be $\left(\beta_{1}+\beta_{2}\right) \%$. If there is cost stickiness, then $\beta_{1}>\beta_{1}+\beta_{2}$ must be established, that is, the sign of $\beta_{2}$ must be negative, which means that firm has cost stickiness.

This paper mainly refers to cost stickiness model of Anderson et al. (2003), Calleja et al. (2006) and Banker et al. (2013), and constructs the following model to analyze the effect of financing constraints on cost stickiness, and the moderating effect of internal control quality on the relationship between them. This paper uses the OLS regression analysis to explore the effect of financing constraints on cost stickiness.

$$
\begin{aligned}
& \log \left(\frac{\operatorname{Cos}_{i, t}}{\operatorname{Cos}_{i, t-1}}\right)=\beta_{0}+\beta_{1} \log \left(\frac{\text { Revenue }_{i, t}}{\text { Revenue }_{i, t-1}}\right)+\beta_{2} \log \left(\frac{\text { Revenue }_{i, t}}{\text { Revenue }_{i, t-1}}\right) \times D_{i, t}+ \\
& \beta_{3} \log \left(\frac{\text { Revenue }_{i, t}}{\text { Revenue }_{i, t-1}}\right) \times D_{i, t} \times F C_{i, t-1}+\sum_{l=4}^{10} \beta_{l} \log \left(\frac{\text { Revenue }_{i, t}}{\text { Revenue }_{i, t-1}}\right) \times D_{i, t} \times \text { Econvar }_{i, t}+ \\
& \sum_{m=11}^{13} \beta_{m} \times F C_{i, t-1}+\sum_{n=14}^{20} \beta_{n} \times \text { Econvar }_{i, t}+\sum \text { Industry }+\sum \text { Year }+\varepsilon_{i, t},
\end{aligned}
$$

where $F C$ is financing constraints, it includes internal financing constraints $(I F)$, debt financing constraints (DF) and equity financing constraints $(E F)$. They are the main independent variables in this paper, and all of them are treated with a lag period. represents the control variables. The interaction term of $F C_{i, t-1}$, Econvar $_{i, t}$ and $D \times \log \left(\right.$ Revenue $_{i, t} /$ Revenue $\left._{i, t-1}\right)$ represents the impact of financing constraints and control variables on cost stickiness. If Model (1) is established, then $\beta_{2}$ must be significantly negative, which means that cost stickiness exists. The main coefficient we focus on is $\beta_{3}$ : the interaction term coefficient between $F C$ and cost stickiness. If the sign of $\beta_{3}$ is positive, it means that financing constraints will weaken cost stickiness; if it is negative, it means financing constraints will strengthen cost stickiness. 


\subsection{Variables}

(1) Independent variable. $\log \left(\operatorname{Cos} t_{i, t} / \operatorname{Cos} t_{i, t-1}\right)$ is the logarithm of cost change rate, ratio representing changes in operating costs, that is, the increase of current operating cost $\left(\operatorname{Cos}_{i, t}\right)$ compared with previous operating cost $\left(\operatorname{Cos}_{i, t-1}\right)$.

(2) Dependent variables. $\log \left(\right.$ Revenue $_{i, t} /$ Revenue $\left._{i, t-1}\right)$ is the logarithm of revenue change rate, ratio representing changes in operating revenue, that is, the increase of current operating

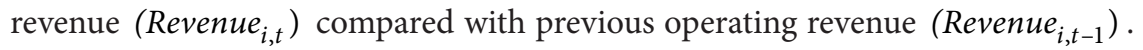

Financing constraints (FC). Firm financing can be divided into internal financing, debt financing and equity financing according to its sources. According to the research ideas of Kaplan and Zingales (2000), Almeida et al. (2004) and other scholars, IF, DF and EF are measured by the ratio of funds obtained by various financing methods to total assets. Specific measurement methods are as follows: using balance sheet data, IF is the proportion of retained earnings (including surplus reserve and undistributed profits) to total assets, DF is the proportion of the sum of long-term and short-term liabilities to total assets, EF is the proportion of paid-in capital (or equity) to total assets.

(3) Moderating variable. Internal control quality (ICQ). This paper uses DIB.China's internal control index as the proxy variable of internal control quality. The higher the index is, the higher the quality of firm's internal control is and the more sound internal control is. This paper takes the logarithm of internal control index.

(4) Control variables.

In order to reduce the interference of missing variables, other control variables that affect cost stickiness are introduced, including Firm size (Size, measured as the logarithm of total assets), Growth ability (Tobin'Q, measured as firm market price/firm reset price), Capital intensity (CI, measured as total assets/total sales), Employee intensity (EI, measured as the number of employees at the end of the year/total sales (in millions)), Asset structure (AS, measured as fixed assets/total assets), Proportion of independent directors (PID, measured as the number of independent directors/the number of board members), Separation of two rights (Separation, measured as the proportion of shares of listed firms directly held by controlling shareholders), Shareholding ratio of controlling shareholders (Share, measured as the difference between control and ownership).

\section{Empirical results}

\subsection{Descriptive statistics}

Table 1 is a descriptive statistic for the main variables. It can be seen from Table 1 that the mean of $\log \left(\right.$ Revenue $_{i, t} /$ Revenue $\left._{i, t-1}\right)$ is 1.230 (the median is 1.114), indicating that Chinese firms' revenue showed an overall growth trend during 2009-2017, and the average growth of revenue change rate was $23 \%$; the mean of $\log \left(\operatorname{Cos} t_{i, t} / \operatorname{Cos} t_{i, t-1}\right)$ is 1.231 (the median is 1.110), indicating that firm cost is also rising, but the growth rate will be faster $0.1 \%(23.1-23 \%)$ than the revenue. As Sun and Liu (2004) have shown, the growth rate of cost faster than that of revenue is an intuitive manifestation of "sticky" cost. The mean of the dummy variable (D) is 0.437 , indicating that $43.7 \%$ of the firms whose operating revenue has declined this year. 
Table 1. Descriptive statistics of main variables

\begin{tabular}{|c|c|c|c|c|c|c|c|}
\hline Variables & $\begin{array}{l}\text { Variable } \\
\text { symbol }\end{array}$ & $\mathrm{N}$ & Mean & SD & $\begin{array}{l}\text { Mini- } \\
\text { mum }\end{array}$ & Median & $\begin{array}{l}\text { Maxi- } \\
\text { mum }\end{array}$ \\
\hline Revenue change rate & & 7512 & 1.230 & 1.943 & 0.118 & 1.114 & 141.2 \\
\hline Cost change rate & & 7512 & 1.231 & 1.847 & 0.119 & 1.110 & 139.8 \\
\hline $\begin{array}{l}\text { Dummy variable of } \\
\text { operating revenue decline }\end{array}$ & $D$ & 7529 & 0.437 & 0.496 & 0 & 0 & 1 \\
\hline Internal financing & IF & 7525 & 0.156 & 0.172 & -0.861 & 0.162 & 0.541 \\
\hline Debt financing & $\mathrm{DF}$ & 7529 & 0.145 & 0.133 & 0 & 0.117 & 0.531 \\
\hline Equity financing & $\mathrm{EF}$ & 7529 & 0.163 & 0.106 & 0.027 & 0.136 & 0.638 \\
\hline Internal control quality & ICQ & 7529 & 6.499 & 0.121 & 5.938 & 6.520 & 6.796 \\
\hline Property rights & SOE & 7529 & 0.368 & 0.482 & 0 & 0 & 1 \\
\hline Firm size & Size & 7529 & 21.91 & 1.159 & 19.81 & 21.74 & 25.36 \\
\hline Growth ability & Tobin'Q & 7311 & 2.312 & 1.821 & 0.235 & 1.800 & 9.855 \\
\hline Capital intensity & $\mathrm{CI}$ & 7529 & 2.046 & 1.213 & 0.413 & 1.752 & 7.288 \\
\hline Asset structure & AS & 7529 & 0.247 & 0.141 & 0.0240 & 0.219 & 0.646 \\
\hline Employee intensity & EI & 7523 & 1.637 & 1.070 & 0.144 & 1.409 & 5.602 \\
\hline $\begin{array}{l}\text { Proportion of } \\
\text { independent directors }\end{array}$ & PID & 7505 & 0.372 & 0.0530 & 0.333 & 0.333 & 0.571 \\
\hline Separation of two right & Separation & 7339 & 0.0590 & 0.0810 & 0 & 0 & 0.289 \\
\hline $\begin{array}{l}\text { Shareholding ratio of } \\
\text { controlling shareholders }\end{array}$ & Share & 7498 & 0.389 & 0.152 & 0.0930 & 0.379 & 0.756 \\
\hline
\end{tabular}

From the descriptive statistics of financing constraints, the mean (0.156) of IF is lower than the median (0.162), indicating that half of manufacturing firms' retained earnings are higher than the industry average level; the mean of DF is 0.145 , which indicates that the overall debt ratio of firm is low, and the maximum value is 0.531 , which means that quite a number of firms face high financial risks; the mean of EF is 0.163 and the median is 0.136 , it shows that half of firms in manufacturing industry have lower paid-in capital than the average level of industry. But the maximum is 0.683 , which indicates that there are large differences in all listed manufacturing firms. In brief, some basic characteristics of the financing market of listed firms in China's manufacturing industry can be found from the data.

There is a certain gap between the minimum and the maximum of internal control index (ICQ), which means that there are differences in the internal control quality of Chinese listed firms, which will inevitably aggravate the complexity of the impact of financing constraints on cost stickiness. The mean of property right (SOE) is 0.368 , which indicates that the proportion of state-owned firms in the sample is $36.8 \%$. The mean (21.91) of firm size (Size) is much higher than the standard deviation (1.182), which indicates that there are great differences among sample firms.

From the descriptive statistics of control variables, the mean (2.312) of growth ability (Tobin'Q) is higher than the median (1.800), and the difference between the minimum (0.235) and the maximum (9.855) is large, indicating that there is a large difference in growth ability between listed firms. This phenomenon is also reflected in the capital intensity and 
employee intensity, which have some effect on explaining adjustment cost. From the mean, median and extreme value of the proportion of independent directors, separation of two rights, shareholding ratio of controlling shareholders, Chinese manufacturing listed firms has different levels of firm governance.

\subsection{Regression analysis}

(1) The impact of financing constraints on cost stickiness

Table 2 is the test result for Hypothesis 1 . Column 2 is the test result of Model (1). The coefficient of $D \times \log \left(\right.$ Revenue $_{i, t} /$ Revenue $\left._{i, t-1}\right)$ is significant and negative at the level of $10 \%$, which indicates that there is obvious cost stickiness in Chinese manufacturing listed firms. Specifically, for every $1 \%$ increase in revenue, costs increase by $0.9867 \%$; and for every $1 \%$ decrease in revenue, costs decrease by $0.9671 \%$. This result is consistent with the research conclusion of Anderson et al. (2003), and Sun and Liu (2004). However, compared with the results of Anderson et al. (2003), cost stickiness of Chinese firms is more serious than that of American firms. Columns 3-6 are the test results of Model (2). It can be seen from the column 3 , the coefficient of $D \times \log \left(\right.$ Revenue $_{i, t} /$ Revenue $\left._{i, t-1}\right) \times I F$ is significantly negative, the coefficient of $D \times \log \left(\right.$ Revenue $_{i, t} /$ Revenue $\left._{i, t-1}\right) \times D F$ and $D \times \log \left(\right.$ Revenue $_{i, t} /$ Revenue $\left._{i, t-1}\right) \times E F$ are both significantly positive, which indicating that internal financing constraints can reinforce cost stickiness, and debt financing constraints and equity financing constraints can mitigate

Table 2. Regression results of financing constraints on cost stickiness

\begin{tabular}{|c|c|c|c|c|c|}
\hline Variables & Model (1) & All samples & $\begin{array}{l}\text { Internal } \\
\text { financing }\end{array}$ & $\begin{array}{c}\text { Debt } \\
\text { financing }\end{array}$ & $\begin{array}{l}\text { Equity } \\
\text { financing }\end{array}$ \\
\hline $\log \left(\right.$ Revenue $_{i, t} /$ Revenue $\left._{i, t-1}\right)$ & $\begin{array}{c}0.9867^{* * *} \\
(194.31)\end{array}$ & $\begin{array}{l}0.9847^{\star * *} \\
(112.61)\end{array}$ & $\begin{array}{l}0.9824^{\star * *} \\
(110.84)\end{array}$ & $\begin{array}{l}0.9824^{\star * *} \\
(111.57)\end{array}$ & $\begin{array}{c}0.9827^{* * *} \\
(111.44)\end{array}$ \\
\hline$D \times\left(\right.$ Revenue $_{i, t} /$ Revenue $\left._{i, t-1}\right)$ & $\begin{array}{c}-0.0196^{*} \\
(-1.70)\end{array}$ & $\begin{array}{l}1.5549^{* * *} \\
(4.01)\end{array}$ & $\begin{array}{l}1.4176^{* * *} \\
(3.78)\end{array}$ & $\begin{array}{l}1.5389^{* * *} \\
(4.05)\end{array}$ & $\begin{array}{l}1.5009^{* * *} \\
(3.98)\end{array}$ \\
\hline$D \times\left(\right.$ Revenue $_{i, t} /$ Revenue $\left._{i, t-1}\right) \times I F$ & & $\begin{array}{c}-0.4460^{* * *} \\
(-3.22)\end{array}$ & $\begin{array}{l}-0.1042 \\
(-1.07)\end{array}$ & & \\
\hline $\begin{array}{l}D \times\left(\text { Revenue }_{i, t} / \text { Revenue }_{i, t-1}\right) \times \\
D F\end{array}$ & & $\begin{array}{l}0.3804^{* * *} \\
(3.31)\end{array}$ & & $\begin{array}{l}0.4721^{* * *} \\
(4.93)\end{array}$ & \\
\hline $\begin{array}{l}D \times\left(\text { Revenue }_{i, t} / \text { Revenue }_{i, t-1}\right) \times \\
E F\end{array}$ & & $\begin{array}{l}0.4440^{* *} \\
(2.56)\end{array}$ & & & $\begin{array}{l}0.3698^{* * *} \\
(3.06)\end{array}$ \\
\hline Control Variables & YES & YES & YES & YES & YES \\
\hline Constant & $\begin{array}{l}0.0007 \\
(0.53)\end{array}$ & $\begin{array}{l}0.0867^{* *} \\
(2.36)\end{array}$ & $\begin{array}{l}0.1228^{\star * *} \\
(3.60)\end{array}$ & $\begin{array}{l}0.1361^{* * *} \\
(4.03)\end{array}$ & $\begin{array}{l}-0.1384^{* * *} \\
(4.05)\end{array}$ \\
\hline Industry \& Year & YES & YES & YES & YES & YES \\
\hline Adj. $R^{2}$ & 0.9104 & 0.9139 & 0.9119 & 0.9126 & 0.9123 \\
\hline $\mathrm{N}$ & 5848 & 4123 & 4123 & 4123 & 4123 \\
\hline
\end{tabular}

Note: $\mathrm{t}$ is the value in parentheses, ${ }^{* *}$ means $1 \%$ level is significant, ${ }^{* *}$ means $5 \%$ level is significant, ${ }^{*}$ means $10 \%$ level is significant. The same below. Limited to the space, only the coefficient of the main dependent variables and interaction term are reported in Tables 2-8. The coefficients of other variables are not reported, and the words "Control variables" are used instead. 
cost stickiness. Because the financing cost of each source is different, the impact of financing constraints on cost stickiness is significantly different. Columns 4-6 provides information about the impact of internal financing, debt financing and equity financing constraints on cost stickiness, respectively. The results are consistent with those of column 3 , although the intensifying effect of internal financing constraints on cost stickiness is not significant. The reason may be that with the continuous development of the capital market, firms can more effectively alleviate the financing constraints through external sources, so internal financing cost is reduced and the speed of overall cost adjustment is accelerated. Therefore, the effect of internal financing constraints on cost stickiness is no longer significant. Based on the above analysis, Hypothesis 1 is established.

(2) The moderation effect of internal control quality

Table 3 is the test result of Hypothesis 2. According to the median of internal control quality (ICQ), this paper divides the sample firms into two groups: high ICQ (ICQ >= median) and low ICQ (ICQ <median), and discussed the changes of cost stickiness in internal financing, debt financing and equity financing constraints respectively.

In high ICQ group, the interaction term coefficients of internal financing, debt financing, equity financing constraints and cost stickiness are all significant and positive, which shows that high ICQ has a weakening effect on cost stickiness. In other words, firms with high ICQ may face smaller financing constraints. In low ICQ group, the interaction term coefficients of internal financing constraints and cost stickiness were significantly negative, while the interaction term coefficients of debt financing constraints and equity financing constraints with cost stickiness were still significantly positive. It shows that cost stickiness will be en-

Table 3. Regression results of the moderation effect of internal control quality

\begin{tabular}{|c|c|c|c|c|c|c|}
\hline \multirow{2}{*}{ Variables } & \multicolumn{2}{|c|}{ Internal financing } & \multicolumn{2}{|c|}{ Debt financing } & \multicolumn{2}{|c|}{ Equity financing } \\
\hline & High ICQ & Low ICQ & High ICQ & Low ICQ & High ICQ & Low ICQ \\
\hline $\begin{array}{l}\log \left(\text { Revenue }_{i, t} l\right. \\
\left.\text { Revenue }_{i, t-1}\right)\end{array}$ & $\begin{array}{l}0.9955^{* * *} \\
(70.43)\end{array}$ & $\begin{array}{c}0.9537^{* * *} \\
(54.37) \\
\end{array}$ & $\begin{array}{l}0.9929^{* * *} \\
(69.09)\end{array}$ & $\begin{array}{c}0.9551^{* * *} \\
(54.64)\end{array}$ & $\begin{array}{c}0.9929^{* * *} \\
(69.19)\end{array}$ & $\begin{array}{c}0.9545^{* * *} \\
(53.76) \\
\end{array}$ \\
\hline $\begin{array}{l}D \times\left(\text { Revenue }_{i, t} /\right. \\
\left.\text { Revenue }_{i, t-1}\right)\end{array}$ & $\begin{array}{c}3.0785^{\star} \\
(1.85) \\
\end{array}$ & $\begin{array}{c}1.5435^{\star * *} \\
(3.07) \\
\end{array}$ & $\begin{array}{c}3.0736^{*} \\
(1.86) \\
\end{array}$ & $\begin{array}{c}1.6810^{* * *} \\
3.30) \\
\end{array}$ & $\begin{array}{c}3.0616^{*} \\
(1.85) \\
\end{array}$ & $\begin{array}{c}1.7159^{* * *} \\
(3.44) \\
\end{array}$ \\
\hline $\begin{array}{l}D \times\left(\text { Revenue }_{i, t} /\right. \\
\left.\text { Revenue }_{i, t-1}\right) \times I F\end{array}$ & $\begin{array}{c}0.3913^{*} \\
(1.94)\end{array}$ & $\begin{array}{c}-0.2639^{*} \\
(-1.87) \\
\end{array}$ & & & & \\
\hline $\begin{array}{l}D \times\left(\text { Revenue }_{i, t}\right. \\
\left./ \text { Revenue }_{i, t-1}\right) \\
\times D F\end{array}$ & & & $\begin{array}{l}0.4182^{\star *} \\
(2.01)\end{array}$ & $\begin{array}{c}0.5346^{* * *} \\
(3.86)\end{array}$ & & \\
\hline $\begin{array}{l}D \times\left(\text { Revenue }_{i, t} /\right. \\
\left.\text { Revenue }_{i, t-1}\right) \times E F\end{array}$ & & & & & $\begin{array}{l}0.4926^{* * *} \\
(2.61)\end{array}$ & $\begin{array}{l}0.4142^{* * *} \\
(2.58)\end{array}$ \\
\hline Control Variables & $\begin{array}{c}0.0274 \\
(0.54)\end{array}$ & $\begin{array}{c}0.0568 \\
(0.66)\end{array}$ & $\begin{array}{l}0.1483 \\
(0.29)\end{array}$ & $\begin{array}{c}0.0725 \\
(0.85)\end{array}$ & $\begin{array}{l}-0.0118 \\
(-0.21)\end{array}$ & $\begin{array}{c}0.0932 \\
(1.10)\end{array}$ \\
\hline Constant & YES & YES & YES & YES & YES & YES \\
\hline Industry \& Year & YES & YES & YES & YES & YES & YES \\
\hline Adj. $R^{2}$ & 0.9089 & 0.9026 & 0.9083 & 0.9038 & 0.9083 & 0.9034 \\
\hline $\mathrm{N}$ & 1207 & 1293 & 1207 & 1293 & 1207 & 1293 \\
\hline
\end{tabular}


hanced when ICQ is low, but the weakening effect of external financing constraints on cost stickiness is not affected by ICQ.

The reason may be that firms relying on internal financing generally face greater financing constraints, while internal control weakness will reduce the decision efficiency of resource adjustment and increase the difficulty of adjusting costs. Therefore, cost stickiness is enhanced. But when the external financing environment is improved, even firms with internal control weakness will benefit from the external financing market. They adjust the cost through effective financing to improve the efficiency of resource allocation, so cost stickiness gradually weakens. Therefore, there is no difference in the moderation effect of ICQ on financing constraints and cost stickiness when they turn to external financing. Hypothesis 2 holds.

(3) Heterogeneity analysis

Heterogeneity of property rights. The impact of financing constraints on cost stickiness is also different in firms with different property rights. This section mainly discusses the impact of internal financing, debt financing and equity financing constraints on cost stickiness of firms with different property rights. According to the ownership, the sample firms are divided into state-owned firms (SOE) and private firms (PE). Table 4 is the test results of distinguishing the property rights.

From the results of whole sample, the coefficients of $D \times \log \left(\right.$ Revenue $_{i, t} /$ Revenue $\left._{i, t-1}\right) \times S O E$ is positive but not significant, which shows that the weakening effect of financing constraints on cost stickiness is not obvious in SOE compared with PE, which means that there is no difference in production and investment circumstance between SOE and PE. From the perspective of different financing constraints, internal financing constraints will enhance cost stickiness while external financing constraints will weaken cost stickiness. However, the enhancement effect is not tenable because the coefficient of $D \times \log \left(\right.$ Revenue $_{i, t} /$ Revenue $\left._{i, t-1}\right) \times I F$ is not significant. The above results mean that with the improvement of Chinese economic marketization level and the improvement of the capital market system, firms begin to turn their attention to external sources to ease financing constraints, and PE gradually enjoys the same financing treatment as SOE. Therefore, the increasing effect of internal financing constraints on cost stickiness is no longer significant, and the weakening effect of debt financing constraints and equity financing constraints on cost stickiness is still significant, but this conclusion no longer strictly distinguishes the property rights of firms.

Heterogeneity of firm size. Generally, large-size firms often have more production and management resources and take possession of more capital, but investment cost in firm operation is higher. Therefore, cost adjustment will be relatively difficult. On the contrary, small-size firms have a weak ability to deal with risks. It means that they need to adjust their costs in time to minimize risks to avoid loss. Table 5 introduces firm size variable in the discussion of the impact of financing constraints on cost stickiness.

According to the median of firm size, the samples are divided into large-size firms (firm size $>=$ median) and small-size firms (firm size $<$ median). From the coefficient of $D \times \log \left(\right.$ Revenue $_{i, t} /$ Revenue $\left._{i, t-1}\right) \times I F$, the internal financing constraints of small-size firms can promote cost stickiness while they can inhibit cost stickiness of large-size firms, but they are not significant. Under debt financing and equity financing constraints, the coefficients of $D \times \log \left(\right.$ Revenue $_{i, t} /$ Revenue $\left._{i, t-1}\right) \times D F$ and $D \times \log \left(\right.$ Revenue $_{i, t} /$ Revenue $\left._{i, t-1}\right) \times E F$ are sig- 


\begin{tabular}{|c|c|c|c|c|c|c|c|c|c|c|c|c|}
\hline \multirow{3}{*}{ 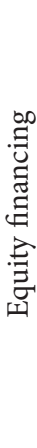 } & 뎀 & 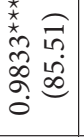 & 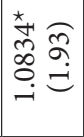 & & & 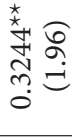 & & $\begin{array}{ll}\substack{x \\
x \\
x} & 0 \\
0 & 0 \\
1 & 0 \\
0 & 0 \\
0 & 0\end{array}$ & $\underset{1}{D}$ & 至 & 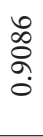 & 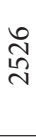 \\
\hline & 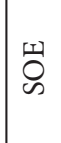 & 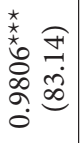 & 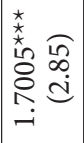 & & & 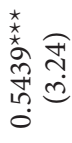 & & $\begin{array}{ll} & 0 \\
0 & 0 \\
0 & + \\
0 & 0 \\
0 & 1\end{array}$ & $\stackrel{2}{\underline{T}}$ & 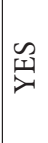 & 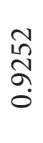 & 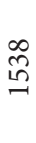 \\
\hline & 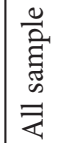 & 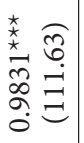 & 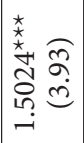 & & & 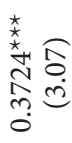 & $\begin{array}{ll}\frac{1}{2} & \widehat{n} \\
8 & 0 \\
0 & 0 \\
0 & 0\end{array}$ & 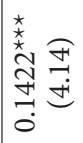 & 足 & 岱 & $\frac{\tilde{a}}{\tilde{\sigma}}$ & $\stackrel{\overbrace{}}{\exists}$ \\
\hline \multirow{3}{*}{ 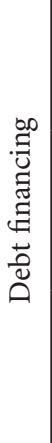 } & 됨 & 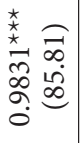 & 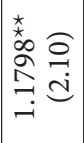 & & 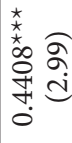 & & & 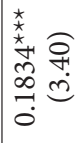 & 望 & 岱 & 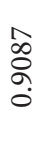 & 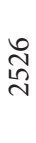 \\
\hline & 留 & 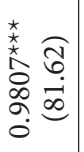 & 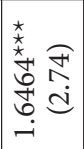 & & 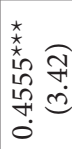 & & & 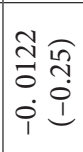 & 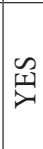 & 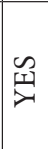 & $\begin{array}{l}n \\
\underline{n} \\
\hat{\sigma}\end{array}$ & $\stackrel{\infty}{\stackrel{\infty}{n}}$ \\
\hline & 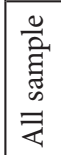 & 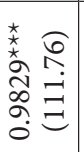 & 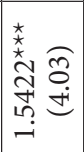 & & 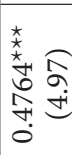 & & 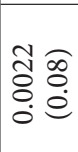 & 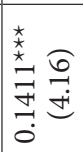 & 望 & 先 & 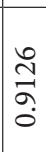 & $\stackrel{\stackrel{\vartheta}{\exists}}{\xi}$ \\
\hline \multirow{3}{*}{ 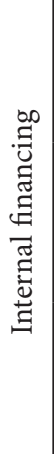 } & 䆓 & 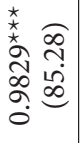 & 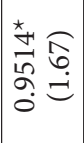 & 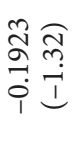 & & & & 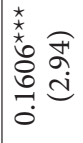 & 望 & 岱 & 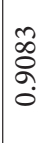 & $\begin{array}{l}\text { त्र } \\
\text { ָூ }\end{array}$ \\
\hline & 핑 & 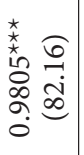 & 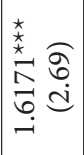 & $\begin{array}{l}\mathbb{H} \widehat{I} \\
0 \\
0 \\
0 \\
1 \\
1\end{array}$ & & & & $\begin{array}{ll}\infty & 0 \\
m & 0 \\
0 & 0 \\
0 & 0 \\
1 & 1\end{array}$ & 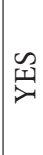 & 至 & 文 & $\stackrel{\infty}{\Omega}$ \\
\hline & 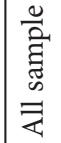 & 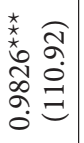 & 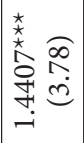 & $\begin{array}{l}0 \\
0 \\
0 \\
0 \\
0 \\
1 \\
1\end{array}$ & & & 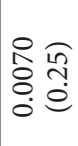 & 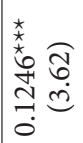 & 出 & 岱 & $\begin{array}{l}\hat{\sigma} \\
\bar{\sigma} \\
\hat{\sigma}\end{array}$ & 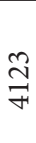 \\
\hline 8 & لَّ & 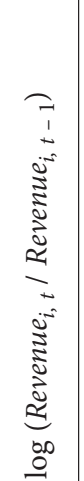 & 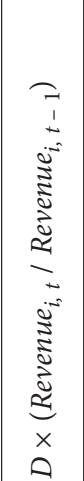 & 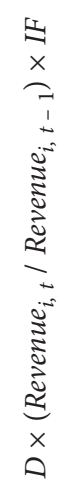 & 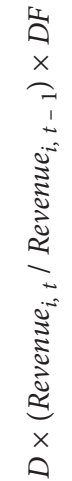 & 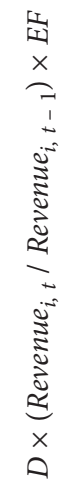 & 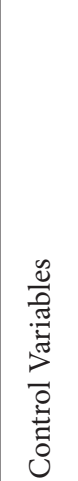 & 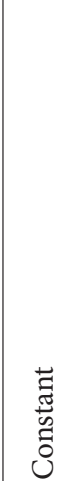 & 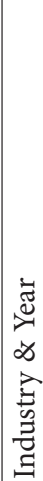 & $\begin{array}{l}\approx \\
\approx \\
: \bar{z}\end{array}$ & z & Z \\
\hline
\end{tabular}


nificantly positive. However, debt financing and equity financing constraints in large-size firms have more significant inhibition on cost stickiness compared with small-size firms. This shows that no matter firm size, the impact of internal financing constraints on cost stickiness is not significant, but debt financing and equity financing constraints have more significant inhibition on cost stickiness in large-size firms than in small ones. The reason may be that with the continuous expansion of firm size, the impact of internal financing constraints on firms is gradually declining. Therefore, more financing sources turn to the external capital market which is in order to expand reproduction. Firms should reduce cost stickiness by more effective resource allocation and cost management in order to better compensate financial expenses caused by external financing constraints and obtain the qualification of refinancing.

Table 5. Regression results of financing constraints, firm size and cost stickiness

\begin{tabular}{|c|c|c|c|c|c|c|}
\hline \multirow[b]{2}{*}{ Variables } & \multicolumn{2}{|c|}{ Internal financing } & \multicolumn{2}{|c|}{ Debt financing } & \multicolumn{2}{|c|}{ Equity financing } \\
\hline & $\begin{array}{l}\text { Large-size } \\
\text { firm }\end{array}$ & $\begin{array}{l}\text { Small-size } \\
\text { firm }\end{array}$ & $\begin{array}{l}\text { Large-size } \\
\text { firm }\end{array}$ & $\begin{array}{l}\text { Small-size } \\
\text { firm }\end{array}$ & $\begin{array}{l}\text { Large-size } \\
\text { firm }\end{array}$ & $\begin{array}{l}\text { Small-size } \\
\text { firm }\end{array}$ \\
\hline $\begin{array}{l}\log \left(\text { Revenue }_{i, t} /\right. \\
\left.\text { Revenue }_{i, t-1}\right)\end{array}$ & $\begin{array}{l}1.0001^{* * *} \\
(78.66)\end{array}$ & $\begin{array}{c}0.9750^{* * *} \\
(60.16)\end{array}$ & $\begin{array}{c}0.9937^{\star * *} \\
(77.21)\end{array}$ & $\begin{array}{c}0.9763^{* * *} \\
(60.82)\end{array}$ & $\begin{array}{l}0.9938^{* * *} \\
(77.27)\end{array}$ & $\begin{array}{c}0.9756^{* * *} \\
(60.99)\end{array}$ \\
\hline $\begin{array}{l}D \times\left(\text { Revenue }_{i, t} /\right. \\
\left.\text { Revenue }_{i, t}-1\right)\end{array}$ & $\begin{array}{l}1.9832^{* *} \\
(2.32)\end{array}$ & $\begin{array}{l}0.1909 \\
(0.20)\end{array}$ & $\begin{array}{c}2.0345^{\star *} \\
(2.41)\end{array}$ & $\begin{array}{l}0.3737 \\
(0.41)\end{array}$ & $\begin{array}{l}1.9595^{* *} \\
(2.32)\end{array}$ & $\begin{array}{l}0.2814 \\
(0.30)\end{array}$ \\
\hline $\begin{array}{l}D \times\left(\text { Revenue }_{i, t} /\right. \\
\left.\text { Revenue }_{i, t-1}\right) \times I F\end{array}$ & $\begin{array}{l}0.1806 \\
(1.55)\end{array}$ & $\begin{array}{l}-0.0997 \\
(-0.61)\end{array}$ & & & & \\
\hline $\begin{array}{l}D \times\left(\text { Revenue }_{i, t} /\right. \\
\left.\text { Revenue }_{i, t-1}\right) \times D F\end{array}$ & & & $\begin{array}{l}0.5149^{* * *} \\
(4.57)\end{array}$ & $\begin{array}{c}0.4691^{* *} \\
(2.10)\end{array}$ & & \\
\hline $\begin{array}{l}D \times\left(\text { Revenue }_{i, t} /\right. \\
\left.\text { Revenue }_{i, t-1}\right) \times E F\end{array}$ & & & & & $\begin{array}{l}0.6894^{* * *} \\
(4.51)\end{array}$ & $\begin{array}{l}0.2529^{*} \\
(1.69)\end{array}$ \\
\hline Control Variables & $\begin{array}{c}0.0875^{\star} \\
(1.93)\end{array}$ & $\begin{array}{l}0.0979 \\
(0.73)\end{array}$ & $\begin{array}{c}0.0907^{\star *} \\
(2.00)\end{array}$ & $\begin{array}{l}0.1329 \\
(0.98)\end{array}$ & $\begin{array}{l}0.0837 \\
(1.63)\end{array}$ & $\begin{array}{l}0.1071 \\
(0.79)\end{array}$ \\
\hline Constant & YES & YES & YES & YES & YES & YES \\
\hline Industry \& Year & YES & YES & YES & YES & YES & YES \\
\hline Adj. $R^{2}$ & 0.9170 & 0.8988 & 0.9169 & 0.8993 & 0.9166 & 0.8991 \\
\hline $\mathrm{N}$ & 2140 & 1672 & 2140 & 1672 & 2140 & 1672 \\
\hline
\end{tabular}

\subsection{Robustness test}

This paper analyzes the effect of financing constraints from different sources on cost stickiness. Using sales and management expenses (S\&M), total cost (Sum of operating costs and S\&M expenses) instead of operating costs to perform operations similar to the Hypothesis 1 to ensure the robustness of the results. The results are shown in Table 6 and Table 7 respectively.

From the Model (1) of the two tables, the coefficients of $D \times \log \left(\right.$ Revenue $\left._{i, t} / \operatorname{Revenuev}_{i, t-1}\right)$ are significant and negative, which indicates that the manufacturing listed firms have cost stickiness. From the estimation results of the whole sample, internal financing constraints 
have significant enhancement effects on cost stickiness, expense stickiness and total cost stickiness, while debt financing constraints and equity financing constraints have the opposite effect, the test results are consistent with Hypothesis 1. According to the results of each financing constraints, debt financing constraints and equity financing constraints still have

Table 6. Regression results of financing constraints on S\&M expense stickiness

\begin{tabular}{|l|c|c|c|c|c|}
\hline \multicolumn{1}{|c|}{ Variables } & Model (1) & All samples & $\begin{array}{c}\text { Internal } \\
\text { financing }\end{array}$ & $\begin{array}{c}\text { Debt } \\
\text { financing }\end{array}$ & $\begin{array}{c}\text { Equity } \\
\text { financing }\end{array}$ \\
\hline $\log \left(\right.$ Revenue $_{i, t} /$ Revenue $\left._{i, t-1}\right)$ & $\begin{array}{c}0.6203^{* * *} \\
(34.56)\end{array}$ & $\begin{array}{c}0.6154^{* * *} \\
(27.66)\end{array}$ & $\begin{array}{c}0.6128^{* * *} \\
(27.08)\end{array}$ & $\begin{array}{c}0.6129^{* * *} \\
(27.76)\end{array}$ & $\begin{array}{c}0.6132^{* * *} \\
(27.16)\end{array}$ \\
\hline$D \times\left(\right.$ Revenue $_{i, t} /$ Revenue $\left._{i, t-1}\right)$ & $\begin{array}{c}-0.2610^{* * *} \\
(-7.17)\end{array}$ & $\begin{array}{c}-1.0471 \\
(-1.26)\end{array}$ & $\begin{array}{c}-1.2944 \\
(-1.62)\end{array}$ & $\begin{array}{c}-1.0542 \\
(-1.29)\end{array}$ & $\begin{array}{c}-1.1366 \\
(-1.39)\end{array}$ \\
\hline $\begin{array}{l}D \times\left(\text { Revenue }_{i, t} / \text { Revenue }_{i, t-1}\right) \\
\times I F\end{array}$ & & $\begin{array}{c}-0.4016^{*} \\
(-1.66)\end{array}$ & $\begin{array}{c}0.3654^{* *} \\
(2.01)\end{array}$ & & \\
\hline $\begin{array}{l}D \times\left(\text { Revenue }_{i, t} / \text { Revenue }_{i, t-1}\right) \\
\times D F\end{array}$ & & $\begin{array}{c}0.8578^{* * *} \\
(3.40)\end{array}$ & & $\begin{array}{c}1.2375^{* * *} \\
(6.06)\end{array}$ & \\
\hline $\begin{array}{l}D \times\left(\text { Revenue }_{i, t} / \text { Revenue }_{i, t-1}\right) \\
\times \text { EF }^{*}\end{array}$ & & $\begin{array}{c}0.8857^{* * *} \\
(3.09)\end{array}$ & & & $1.1072^{* * *}$ \\
\hline Control Variables & $0.1074^{*}$ & $\begin{array}{c}-0.3188^{* * *} \\
(-4.09)\end{array}$ & $\begin{array}{c}-0.3278^{* * *} \\
(-4.33)\end{array}$ & $\begin{array}{c}-0.3253^{* * *} \\
(-4.30)\end{array}$ & $\begin{array}{c}-0.2669^{* * *} \\
(-3.50)\end{array}$ \\
\hline Constant & $(1.86)$ & YES & YES & YES & YES \\
\hline Industry \& Year & YES & YES & YES & YES & YES \\
\hline Adj. $R^{2}$ & 0.4494 & 0.4632 & 0.4518 & 0.4596 & 0.4573 \\
\hline $\mathrm{N}$ & 5848 & 4123 & 4123 & 4123 & 4123 \\
\hline
\end{tabular}

Table 7. Regression results of financing constraints on total cost stickiness

\begin{tabular}{|c|c|c|c|c|c|}
\hline Variables & Model (1) & All samples & $\begin{array}{l}\text { Internal } \\
\text { financing }\end{array}$ & $\begin{array}{c}\text { Debt } \\
\text { financing }\end{array}$ & $\begin{array}{l}\text { Equity } \\
\text { financing }\end{array}$ \\
\hline $\log \left(\right.$ Revenue $_{i, t} /$ Revenue $\left._{i, t-1}\right)$ & $\begin{array}{c}0.9207^{* * *} \\
156.21)\end{array}$ & $\begin{array}{l}0.9211^{* * *} \\
(128.48)\end{array}$ & $\begin{array}{l}0.9188^{* * *} \\
(123.86)\end{array}$ & $\begin{array}{l}0.9187^{* * *} \\
(126.34)\end{array}$ & $\begin{array}{l}0.9192^{* * *} \\
(125.79)\end{array}$ \\
\hline$D \times\left(\right.$ Revenue $_{i, t} /$ Revenue $\left._{i, t-1}\right)$ & $\begin{array}{c}-0.0633^{* * *} \\
(-4.52)\end{array}$ & $\begin{array}{l}1.1506^{* * *} \\
(2.79)\end{array}$ & $\begin{array}{l}0.9875^{\star *} \\
(2.52)\end{array}$ & $\begin{array}{c}1.1363^{* * *} \\
(2.83)\end{array}$ & $\begin{array}{l}1.0902^{* * *} \\
(2.75)\end{array}$ \\
\hline $\begin{array}{l}D \times\left(\text { Revenue }_{i, t} / \text { Revenue }_{i, t-1}\right) \\
\times I F\end{array}$ & & $\begin{array}{c}-0.4186^{* * *} \\
(-3.02)\end{array}$ & $\begin{array}{c}0.0456 \\
(0.51)\end{array}$ & & \\
\hline $\begin{array}{l}D \times\left(\text { Revenue }_{i, t} / \text { Revenue }_{i, t-1}\right) \\
\times D F\end{array}$ & & $\begin{array}{l}0.4687^{* * *} \\
(3.93)\end{array}$ & & $\begin{array}{l}0.6605^{* * *} \\
(6.30)\end{array}$ & \\
\hline $\begin{array}{l}D \times\left(\text { Revenue }_{i, t} / \text { Revenue }_{i, t-1}\right) \\
\times E F\end{array}$ & & $\begin{array}{l}0.5908^{\star * *} \\
(3.45)\end{array}$ & & & $\begin{array}{l}0.5848^{* * *} \\
(4.83)\end{array}$ \\
\hline Control Variables & $\begin{array}{l}-0.0460 \\
(-1.22) \\
\end{array}$ & $\begin{array}{l}0.0095 \\
(0.32)\end{array}$ & $\begin{array}{c}0.0290 \\
(1.03)\end{array}$ & $\begin{array}{c}0.0396 \\
(1.42)\end{array}$ & $\begin{array}{c}0.0571^{\star *} \\
(2.03)\end{array}$ \\
\hline Constant & & YES & YES & YES & YES \\
\hline Industry \& Year & YES & YES & YES & YES & YES \\
\hline Adj. $R^{2}$ & 0.9279 & 0.9319 & 0.9286 & 0.9304 & 0.9299 \\
\hline $\mathrm{N}$ & 5848 & 4123 & 4123 & 4123 & 4123 \\
\hline
\end{tabular}


significant dampen effects on cost stickiness and total cost stickiness. However, the effect of internal financing constraints on cost stickiness and total cost stickiness has changed from strengthening to weakening, but this result is not significant in total cost stickiness.

The reason may be that the development of market economy promotes the improvement of capital market and external financing becomes the main capital source for firms. However, this change also intensifies the competition intensity of capital market, and the choice of combined financing strategy is more effective than a single financing source to solve the capital demand of firms. Firms can effectively share and reduce financing costs through a variety of financing sources, to reduce the overall adjustment cost and improve the efficiency of resource allocation. Therefore, internal financing constraints will gradually turn to weaken cost stickiness just like external financing constraints. This shows that the conclusion is robust and reasonable.

\subsection{Endogenous test}

The above research shows that there are significant differences in the impact of financing constraints on cost stickiness. However, it is not enough to infer that financing constraint is the cause of the change of cost stickiness. For example, compared with private firms, public firms can better disperse the risk of capital market, so it is easier to access equity financing (Choi et al., 2017); a higher level of governance will be accompanied by lower cost stickiness (Chen et al., 2012). Therefore, the relationship between financing constraints and cost stickiness will be disturbed by sample selection bias. In this paper, panel fixed effect and Heckman two-stage regression are used to overcome this problem. Table 8 reports the test results.

In the first solution, the Hausman test shows that the fixed effect model is the most effective and reasonable because the p-value is 0.0000 , and the original hypothesis of random effect is strongly rejected. It can be seen from the column (1), the coefficient of $D \times \log \left(\right.$ Revenue $_{i, t} /$ Revenue $\left._{i, t-1}\right) \times I F$ is significantly negative, while the coefficient of $D \times \log \left(\right.$ Revenue $_{i, t} /$ Revenue $\left._{i, t-1}\right) \times D F$ and $D \times \log \left(\right.$ Revenue $_{i, t} /$ Revenue $\left._{i, t-1}\right) \times E F$ are both significantly positive, which indicating that internal financing constraints can reinforce cost stickiness, and debt financing constraints and equity financing constraints can mitigate cost stickiness. This is consistent with the previous results.

In the second solution, through the selection model of the first stage, the results of regression show that Tobin'Q is positively correlated with IF and EF, AS is positively correlated with DF and EF, PID and Size are positively correlated with DF, but Size is positively correlated with IF and EF, EF is negatively correlated, Share is negatively correlated with DF and EF, AS and EI are negatively correlated with IF. The Inverse Mills ratio calculated by the first stage model is incorporated into the Model (1) and repeat the regression of Model (1). After controlling the sample selection bias, the regression results show that: internal financing constraints have a significant promoting effect on cost stickiness, while debt financing constraints and equity financing constraints have a significant restraining effect on cost stickiness. Overall, the conclusions of this paper are robust. 
Table 8. Discussion of endogenous issues

\begin{tabular}{|c|c|c|c|c|c|c|c|}
\hline \multirow[b]{2}{*}{ Variables } & \multicolumn{4}{|c|}{ Panel fixed effect regression } & \multicolumn{3}{|c|}{ Heckman two-stage model } \\
\hline & $\begin{array}{c}\text { All } \\
\text { samples } \\
(1)\end{array}$ & $\begin{array}{c}\text { Internal } \\
\text { financing } \\
(2)\end{array}$ & $\begin{array}{c}\text { Debt } \\
\text { financing } \\
(3)\end{array}$ & $\begin{array}{c}\text { Equity } \\
\text { financing } \\
(4)\end{array}$ & $\begin{array}{c}\text { Internal } \\
\text { financing } \\
\text { (5) }\end{array}$ & $\begin{array}{c}\text { Debt } \\
\text { financing } \\
(6)\end{array}$ & $\begin{array}{c}\text { Equity } \\
\text { financing } \\
(7)\end{array}$ \\
\hline $\begin{array}{l}\log \left(\text { Revenue }_{i, t} l^{\prime}\right. \\
\left.\text { Revenue }_{i, t-1}\right)\end{array}$ & $\begin{array}{c}0.9847^{* * *} \\
(113.39)\end{array}$ & $\begin{array}{l}0.9808^{* * *} \\
(112.78)\end{array}$ & $\begin{array}{l}0.9817^{\star * *} \\
(112.59)\end{array}$ & $\begin{array}{c}0.9820^{\star * *} \\
(111.93)\end{array}$ & $\begin{array}{l}0.9944^{* * *} \\
(58.59)\end{array}$ & $\begin{array}{c}0.9998^{* * *} \\
(93.52)\end{array}$ & $\begin{array}{l}0.9870^{\star * *} \\
(75.00)\end{array}$ \\
\hline $\begin{array}{l}D \times\left(\text { Revenue }_{i, t} /\right. \\
\left.\text { Revenue }_{i, t-1}\right)\end{array}$ & $\begin{array}{c}1.5203^{* * *} \\
(3.94)\end{array}$ & $\begin{array}{l}1.4516^{* * *} \\
(3.75)\end{array}$ & $\begin{array}{l}1.2950^{* * *} \\
(3.34)\end{array}$ & $\begin{array}{c}1.4028^{* * *} \\
(3.60)\end{array}$ & $\begin{array}{l}1.7273^{* * *} \\
(2.74)\end{array}$ & $\begin{array}{c}2.0890^{* * *} \\
(2.70)\end{array}$ & $\begin{array}{l}1.9345^{* * *} \\
(3.17)\end{array}$ \\
\hline $\begin{array}{l}D \times\left(\text { Revenue }_{i, t}\right. \\
\left./ \text { Revenue }_{i, t}-1\right) \\
\times I F\end{array}$ & $\begin{array}{c}-0.3556^{\star * \star} \\
(-2.89)\end{array}$ & $\begin{array}{c}-0.0421^{\star} \\
(-1.73)\end{array}$ & & & $\begin{array}{c}-0.1176^{*} \\
(-1.02)\end{array}$ & & \\
\hline $\begin{array}{l}D \times\left(\text { Revenue }_{i, t}\right. \\
\left./ \text { Revenue }_{i, t}-1\right) \\
\times D F\end{array}$ & $\begin{array}{c}0.4261^{* * *} \\
(3.74)\end{array}$ & & $\begin{array}{c}0.5205^{\star \star \star} \\
(5.53)\end{array}$ & & & $\begin{array}{c}0.5671^{* * *} \\
(5.69)\end{array}$ & \\
\hline $\begin{array}{l}D \times\left(\text { Revenue }_{i, t}\right. \\
\left./ \text { Revenue }_{i, t}-1\right) \\
\times E F\end{array}$ & $\begin{array}{c}0.4092^{* * *} \\
(2.95)\end{array}$ & & & $\begin{array}{c}0.4182^{\star * *} \\
(4.21)\end{array}$ & & & $\begin{array}{l}0.3880^{* * *} \\
(2.98)\end{array}$ \\
\hline $\begin{array}{l}\text { Inverse Mills } \\
\text { ratio }\end{array}$ & & & & & $\begin{array}{l}0.0217 \\
(1.06)\end{array}$ & $\begin{array}{l}0.0157 \\
(0.81)\end{array}$ & $\begin{array}{l}0.0129 \\
(0.63)\end{array}$ \\
\hline Constant & $\begin{array}{l}0.2554^{* *} \\
(2.09)\end{array}$ & $\begin{array}{c}0.1983^{*} \\
(1.64)\end{array}$ & $\begin{array}{c}0.2163^{\star} \\
(1.79) \\
\end{array}$ & $\begin{array}{c}0.2275^{*} \\
(1.84)\end{array}$ & $\begin{array}{l}0.0892^{* *} \\
(2.23)\end{array}$ & $\begin{array}{l}0.0873 \\
(1.41) \\
\end{array}$ & $\begin{array}{l}0.0538 \\
(0.37)\end{array}$ \\
\hline Control Variables & YES & YES & YES & YES & YES & YES & YES \\
\hline Industry \& Year & YES & YES & YES & YES & YES & YES & YES \\
\hline Adj. $R^{2}$ & 0.8967 & 0.8952 & 0.8946 & 0.8941 & 0.8824 & 0.9193 & 0.8941 \\
\hline $\mathrm{N}$ & 4123 & 4123 & 4123 & 4123 & 2093 & 2134 & 2059 \\
\hline
\end{tabular}

\section{Conclusions}

Cost management is the key link to a firm sustainable operation. Firm cost has been more constrained by managers' discretion since the separation of ownership and management rights. More managers think that it is more effective to retain resources than to rebuild resources after exhausting them due to the uncertainty of production and demand. Cost stickiness arises in the decision-making of resource adjustment. Therefore, cost stickiness can effectively reflect cost behavior of firms. This paper studies the effect of financing constraints on cost stickiness from the perspective of adjustment cost viewpoint. Using panel data of Chinese manufacturing listed firms from 2009 to 2017, the results show that internal financing constraints have a significant promotion effect on cost stickiness, while debt financing constraints and equity financing constraints have a significant restraining effect on cost stickiness. Internal control quality has a moderating effect on this relationship. Compared with firms with high internal control quality, cost stickiness of firms with internal financing constraints will increase when the internal control quality is low, but the weakening effect of external financing on cost stickiness is not affected by internal control quality. From the 
results of heterogeneity analysis, the promoting effect of internal financing constraints on cost stickiness is no longer significant when considering property rights, and the weakening effect of debt financing constraints and equity financing constraints on cost stickiness is still significant. However, this result no longer strictly distinguishes the property rights of firms. No matter the firm size, the effect of internal financing constraints on cost stickiness is not significant, but compared with small-size firms, debt financing constraints and equity financing constraints have a more prominent restraining effect on cost stickiness in large-size firms.

This paper aims to provide practical evidence for solving real problems of overcapacity and high cost in China's real economic firms. Because financing cost will affect the choice of financing sources and discretion-making of managers over resources will cause cost stickiness, so as to find a theoretical fit point for the effect of financing constraints on cost stickiness. This paper analyses the impact of financing cost on resource adjustment from the standpoint of management accounting. This study broadens the research perspective of the factors affecting cost stickiness. The results have implications for future business management. Current management has changed from post-management to pre-supervision, so forecasting plan is becoming more important to the survival of firms. Managers can predict the cost change caused by the change of revenue and affect the resource allocation in decision-making through the analysis of cost behavior. From the perspective of adjusting cost, managers must consider the impact of financing cost, provide sufficient financial support for firms to adjust cost, to investigate the behavior deviation behind the decision of resource allocation.

There are some limitations in this study. First, only the Chinese manufacturing listed firms are used as the research sample, and the above research results are not extended to other industries and lack comparison between different industries. Second, this paper examines the cost behavior of firms from the internal factor of internal control, but does not consider the important role of corporate governance. Therefore, in future research, it will be a useful direction to consider the industry heterogeneity of the above conclusions, and to further incorporate corporate governance into this research framework, such as equity structure and board governance mechanisms.

\section{Funding}

This work was supported by National Natural Science Foundation of China under Grant No. 72174180, No. 71673250; Zhejiang Natural Science Funds for Distinguished Young Scholar under Grant No. LR18G030001; and the Major Projects of the Key Research Base of Humanities under the Ministry of Education under Grant No. 14JJD790019.

\section{Author contributions}

Yufeng Chen: Conceptualization, supervision, writing - review \& editing, Funding acquisition. Yanbai Ma: Conceptualization, data curation, software, methodology, writing - original draft. 


\section{Disclosure statement}

Authors declare that they do not have any competing financial, professional, or personal interests from other parties.

\section{References}

Almeida, H., Campello, M., \& Weisbach, M. (2004). The cash flow sensitivity of cash. The Journal of Finance, 59(43), 1777-1804. https://doi.org/10.1111/j.1540-6261.2004.00679.x

Anderson, M., Banker, R., \& Janakiraman, S. (2003). Are selling, general, and administrative costs "sticky"? Journal of Accounting Research, 41(1), 47-63. https://doi.org/10.1111/1475-679X.00095

Banker, R., Byzalov, D., \& Chen, L. (2013). Employment protection legislation, adjustment costs and cross-country differences in cost behavior. Journal of Accounting and Economics, 51(1), 111-127. https://doi.org/10.1016/j.jacceco.2012.08.003

Banker, R., Byzalov, D., \& Plehn-Dujowich, J. (2011). Sticky cost behavior: Theory and evidence. AAA 2011 Management Accounting Section (MAS) Meeting Paper. https://doi.org/10.2139/ssrn.1659493

Banker, R., \& Johnston, H. (1993). An empirical study of cost drivers in the U.S. airline industry. The Accounting Review, 68(3), 576-601. https://www.jstor.org/stable/248202?seq=1

Baumgarten, D. (2012). Cost stickiness phenomenon: Causes, characteristics and implications for fundamental analysis and financial analysts forecasts. Springer. https://doi.org/10.1007/978-3-8349-4131-2

Bradbury, M., \& Scott, T. (2018). Do managers forecast asymmetric cost behavior? Australian Journal of Management, 43(4), 538-554. https://doi.org/10.1177/0312896218773136

Calleja, K., Steliaros, M., \& Thomas, D. (2006). A note on cost stickiness: Some international comparison. Management Accounting Research, 12(2), 127-140. https://doi.org/10.1016/j.mar.2006.02.001

Campello, M., Graham, J., \& Harvey, C. (2010). The real effects of financial constraints: Evidence from a financial crisis. Journal of Financial Economics, 97(3), 470-487.

https://doi.org/10.1016/j.jfineco.2010.02.009

Chen, C., Lu, H., \& Sougiannis, T. (2012). The agency problem, corporate governance, and the asymmetrical behavior of selling, general, and administrative costs. Contemporary Accounting Research, 29(1), 252-282. https://doi.org/10.1111/j.1911-3846.2011.01094.x

Chen, C., Gores, T., Nasev, J., \& Wu, S. (2021). CFO overconfidence and cost behavior. Journal of Management Accounting Research, 33. https://doi.org/10.2308/JMAR-18-055

Chen, Y., \& Hu, N. (2017). Credit default swaps and cost stickiness. https://doi.org/10.2139/ssrn.3042344

Cheng, Q., Goh, B., \& Kim, J. (2014). Internal control and operational efficiency. Contemporary Accounting Research, 35(2), 1102-1139. https://doi.org/10.1111/1911-3846.12409

Cheng, S., Jiang, W., \& Zeng, Y. (2016). Does access to capital affect cost stickiness? Evidence from China. Asia-Pacific Journal of Accounting \& Economics, 25(1-2), 177-198. https://doi.org/10.1080/16081625.2016.1253483

China Securities Regulatory Commission. (2012). Guidelines for Listed Firms' Industry Classification (Revised 2012). http://www.csrc.gov.cn/pub/zjhpublic/G00306201/201211/t20121116_216990.htm

China Securities Regulatory Commission. (2018). Regulatory Requirements for Guiding and Regulating the Financing Behavior of Listed Firms.

http://www.csrc.gov.cn/pub/newsite/zjhxwfb/xwdd/201811/t20181109_346511.html

Choi, S., Hwang, I., Lee, M., \& Lee, W. (2017). Cost stickiness of private and public firms (Working Paper). https://ssrn.com/abstract=3019762 
Dierynck, B., Landsman, W., \& Renders, A. (2012). Do managerial incentives drive cost behavior? Evidence about the roles of the zero earnings benchmark for labor cost behavior in Belgian private firms. The Accounting Review, 87(4), 1219-1246. https://doi.org/10.2308/accr-50153

Doms, M., \& Dunne, T. (1998). Capital adjustment patterns in manufacturing plants. Review of Economic Dynamics, 1(2), 409-429. https://doi.org/10.1006/redy.1998.0011

Fazzari, S., Hubbard, R., Petersen, B., Blinder, A., \& Poterba, J. (1988). Financing constraints and corporate investment. Brookings Papers on Economic Activity, (1), 141-195. https://doi.org/10.2307/2534426

Hall, B., \& Lerner, J. (2010). The financing of R\&D and innovation. In B. Hall \& N. Rosenberg (Eds), Handbook of the economics of innovation (pp. 609-639). Elsevier. https://doi.org/10.1016/S0169-7218(10)01014-2

Hartlieb, S., Loy, T., \& Eierle, B. (2020a). Does community social capital affect asymmetric cost behaviour? Management Accounting Research, 46, 100640. https://doi.org/10.1016/j.mar.2019.02.002

Hartlieb, S., Loy, T., \& Eierle, B. (2020b). The effect of generalized trust on cost stickiness: Cross-country evidence. The International Journal of Accounting, 55(4), 2050018. https://doi.org/10.1142/S1094406020500183

Hassanein, A., \& Younis, M. (2020). Cost stickiness behavior and financial crisis: Evidence from the UK chemical industry. Corporate Ownership \& Control, 17(2), 46-56. https://doi.org/10.22495/cocv17i2art4

Homburg, C., Hoppe, A., Nasev, J., Reimer, K., \& Uhrig-Homburg, M. (2018). Cost stickiness and credit risk (Working Paper). https://doi.org/10.2139/ssrn.2792085

Jensen, M., \& Meckling, W. (1976). Theory of the firm: Managerial behavior, agency costs and ownership structure. Journal of Financial Economics, 3(4), 305-360. https://doi.org/10.1016/0304-405X(76)90026-X

Kaplan, S., \& Zingales, L. (2000). Investment-cash flow sensitivities are not valid measures of financing constraints. The Quarterly Journal of Economics, 115(2), 707-712. https://doi.org/10.1162/003355300554782

Kim, J., Lee, J., \& Park, J. (2019). Internal control weakness and the asymmetrical behavior of selling, general, and administrative costs. Journal of Accounting, Auditing and Finance. https://doi.org/10.1177/0148558X19868114

Li, W., \& Zheng, K. (2017). Product market competition and cost stickiness. Review of Quantitative Finance and Accounting, 49(2), 283-313. https://doi.org/10.1007/s11156-016-0591-z

Malik, M. (2012). A review and synthesis of "cost stickiness" literature (Working Paper). https://doi.org/10.2139/ssrn.2276760

Navarro, P., Robb, S., Sutton, S., \& Weisner, M. (2020). The cost stickiness of information technology material weaknesses: An intertemporal comparison between it-related and other material weaknesses. International Journal of Accounting Information Systems, 37, 100454.

https://doi.org/10.1016/j.accinf.2020.100454

Noreen, E. (1991). Condition under which activity-based cost systems provided relevant cost. Journal of Management Accounting Research, 3, 159-168. https://cpb-us-w2.wpmucdn.com/u.osu.edu/ dist/8/36875/files/2016/12/Noreen-JMAR-1991-vrlob7.pdf

Noreen, E., \& Soderstrom, N. (1997). The accuracy of proportional cost models: Evidence from hospital service departments. Review of Accounting Studies, 2(1), 89-114. https://doi.org/10.1023/A:1018325711417

Pfann, G., \& Palm, F. (1993). Asymmetric adjustment costs in non-linear labor demand models for the Netherlands and U.K. manufacturing sectors. Review of Economic Studies, 60(2), 397-412. https://doi.org/10.2307/2298064 
Prieto, A. (2019). Does cost stickiness affect capital structure? Evidence from Korea. Journal of Management Accounting Research, 19(2), 27-57. https://doi.org/10.31507/KJMAR.2019.8.19.2.27

Salehi, M., Ziba, N., \& Gah, A. (2018). The relationship between cost stickiness and financial reporting quality in Tehran Stock Exchange. International Journal of Productivity and Performance Management, 67(9), 1550-1565. https://doi.org/10.1108/IJPPM-10-2017-0255

Subramaniam, C., \& Weidenmier, M. (2016). Additional evidence on the sticky behavior of costs. Advances in Management Accounting, 26, 275-305. https://doi.org/10.1108/S1474-787120150000026006

Sun, Z., \& Liu, H. (2004). The expense "stickiness" behavior of Chinese listed firms. Economic Research Journal, 12, 26-34 (in Chinese). https://kns.cnki.net/kcms/detail/detail.aspx?FileName=JJYJ200412003\&DbName=CJFQ2004

Tan, W., \& Ma, Z. (2016). Ownership, internal capital market, and financing costs. Emerging Markets Finance and Trade, 52(5), 1259-1278. https://doi.org/10.1080/1540496X.2016.1138815

Tang, Q. (2020). Cost stickiness, corporate future losses and audit costs. American Journal of Industrial and Business Management, 10(1), 110-134. https://doi.org/10.4236/ajibm.2020.101008

Yasukata, K. (2011). Are "Sticky Costs" the result of deliberate decision of managers? (Working Paper). Kinki University. https://doi.org/10.2139/ssrn.1444746

Zhu, Q., \& Yang, Y. (2019). Study on supply chain finance, internal control and SMEs financing constraints. In Advances in Economics, Business and Management Research: Vol. 91. $1^{\text {st }}$ International Symposium on Economic Development and Management Innovation (EDMI 2019) (pp. 442-449). Atlantis Press. https://doi.org/10.2991/edmi-19.2019.73 